\title{
The Determinants of Financial Development: Empirical Evidence from Developed and Developing Countries
}

\author{
Hamdi Khalfaoui ${ }^{1}$ \\ ${ }^{1}$ PS2D laboratory, Faculty of Economicsand Management, University of Tunis El Manar, Tunisia \\ Correspondence : Hamdi Khalfaoui, 110 cité balaoui, route haffouz, Kairouan 3100, Tunisia
}

Received: June 24, 2015

Accepted: July 14, 2015

Available online: August 10, 2015

doi:10.11114/aef.v2i4.894

URL: http://dx.doi.org/10.11114/aef.v2i4.894

\begin{abstract}
Countries which initiate economic development, use in the most cases, the mechanisms and tools of the financial sphere to maximize the chances of success of their financial development process. However, some financial, economic and institutional conditions are compulsory for the success of the whole process. In this context, our empirical analysis using panel data is applied on two samples divided among 15 developed and 23 developing countries over a period from 1997 to 2013.The result obtained show that financial development determinants are mainly related to banking and financial sector and the level of economic and human development for both samples. Whereas, the determinants related to economic stability and the legal and institutional framework have a significant impact on financial development only in the developed countries.
\end{abstract}

Key words: financial development, macroeconomic stability, legal and institutional environment, developed and developing countries, panel data

\section{Introduction}

The interactions between financial development and real development are an ongoing debate of national and international financial and economic agencies and bodies. Actually, financial development seems to be a fundamental condition required before taking any policy of financial liberalization and consequently for a sustainable economic development. Experience has shown that a hasty financial liberalization without being overtaken by a solid financial development and consistent, will lead to stagnation or economic and financial recession and banking crises. The case of Southeast Asian and Latin American countries of the 90s, illustrate the tragic consequences of early financial liberalization, marginalized and without parapets.

Financial development, which includes both the rehabilitation of the banking system and financial market restructuring, aims to optimize choices and economic financing, optimal allocation of resources and diversification of risk. Conversely,an immature and vulnerable financial system reduces the chances of financing of the economy, strengthens financial repression and encourages speculation.

Today, most of the countries that start a financial liberalization policy and sustainable economic development are convinced that this goal involves the restructuring and the modernization of their financial systems.

The optimization of the relationship between the real economy and the financial sphere and the preponderance of the financial sphere which stimulate economic growth requires a strong and effective banking and financial system, a stable macroeconomic environment and an adequate legal and institutional framework. However, these conditions, although they are feasible, are unavoidable and binding on countries whose initial economic and financial level is low.

In this context, the present paper aim to circumvent the main determinants of financial development and to seek if they are general and generalizable to all countries.

Our empirical analysis using panel data is carried out on two groups of samples, consisting of 15 developed countries and 23 developing countries. The study was spread over a period of 17 years from 1997 to 2013. The results show that the success of financial development process depends on the state of the banking and financial system and on the initial level of economic and human development. Trade liberalization plays an important role in the whole process as well. However, macroeconomic conditions of stability and the legal and institutional environment depend on the particular case of each country. 
The paper is organized as follow: The first section reviews the framework of the relationship between financial development and its main determinants. The second section presents the research methodology including empirical model. The third section shows the results, followed by a general conclusion in the east section.

\section{Literature Review}

Chronologically, Walter Bagehot was one of the first to address the relationship between the financial system and economic growth in his book "Lombard Street: A Description of the Money Market (1873)", he wrote. "What distinguished the industrial power Great Britain from all barbarian countries was the ability of its capital markets to mobilize savings to finance gigantic work" Bagehot identified the capital markets as the easiest path for the accumulation of capital and management of risks often to particular investment projects.

More specifically, the financial development thesis was defended by Bagehot, according to De Gregorio and Guidotti (1995), at two levels. On the one hand, development of the financial system is the best response to various financial service requested to register growth. On the other hand, financial development is presented as an alternative to a regime of financial repression.

In 1912, this theory was explained, according to Arena and Fester (1996), by the writings of J. Schumpeter who had emphasized the primary role of bankers, who by their targeting and financing entrepreneurs, encourage the technological innovation, capital accumulation and thus stimulate growth.

Since then, the theoretical analysis and empirical tests have shown that the development of financial systems is ensured by compliance with economic, financial and institutional conditions. Mac-Kinnon (1991) and Johnston and Pazarbasioglu (1995) point out that budgetary discipline and monetary control is a prerequisite to any successful financial development policy in terms of efficiency and economic growth. Fry (1997) and Beck et al. (2001) argue that the institutional aspects,such as the methods and quality of prudential supervision, should affect the impact of financial liberalization policies on financial development. Laporta et al $(1997,1996)$ showed that the quality of legal standards and laws of contract enforcement are important determinants of the development of capital markets. Rajan and Zingales (2003) argued that political instability hinders financial development process. Grossman and Yanagawa (1993) and Greenwood and Jovanovic (1990) found that the financial market is beneficial in terms of economic growth below a certain economic and financial development threshold.

Initially, we thought that the positive effects of financial development will go through a simple rehabilitation of market mechanisms. Later it turned out that its benefits are strongly conditioned by confronting certain requirements that are difficult to meet simultaneously. Working of the financial system, its structure and its governance have a particular importance for the success of the whole process.

The factors of financial development success usually depend on a stable macroeconomic environment, an appropriate prudential regulation of the banking system of each country, a financial market efficient and rigorous legal and institutional framework. However, the measures taken actually lead to mixed effects on the indispensability of these conditions as guarantees for a successful financial development process. A savings rate and high investment aren't the only guarantee of success, the case of the disappearance of the Soviet Union, in which the savings and investment were important but were not used efficiently confirms the result. Thus the financial system of a country plays a key role in ensuring that savings are invested in an optimal and least risky way.

Empirically, Olivei and Klein (2000) and Edwards (2001) show that financial development by the capital account liberalization, is more effective than a set of mixed conditions relating to economic, legal and institutional structures aresatisfied. Arteta, Eichengreen and Wyplosz (2001), show that the importance of the sequencing of reforms reinforced by the absence of macroeconomic imbalances plays a decisive role on the efficiency of financial development on economic growth. Chinn and Ito (2002), show that financial development effect is even greater than the protection of shareholders and accounting norms standards are observed. Ben Saada and Khalfaoui (2013) revealed that the conditions for financial development success are not essential together but vary according to the financial development of indicator. The results obtained show that the level of the initial economic development and quality of legal and institutional framework is essential. While macroeconomic stability has mixed effects.

Given these empirical work that differ, depending on the method, the data, the sample, the horizon and sometimes the results obtained, we could test the following hypothesis

H1: The determinants of financial development are mainly based on global financial system and are unanimous in all countries regardless of their level of development.

H2: Macroeconomic stability and legal and institutional environment are not inevitable conditions but vary with the particular case of each country. 


\section{Method}

\subsection{Definition of variables}

\subsubsection{The dependent variable}

The dependent variable it is the financial development. It is measured by the volume of domestic credit to the private sector as a percentage of GDP

\subsubsection{The Independent variables}

The Independent variables are the determinants which represent financial and banking system, Initial level of economic and human development, macroeconomic stability and development of legal and institutional framework.

- Financial and banking Variables

A.Non-performing Loans: they represent the most frightening indicator for banks. It also reflects the burden of bad debts in credit risk management. In assessing this risk, banks must distinguish their balance sheet assets and off-balance sheet:

- Current assets: assets with a full recovery in time.

- Assets classified according to risk of loss and the probability of recovery (assets requiring special monitoring, uncertain assets, concern or threatened assets, bad or impaired assets)

B.Broad money as a percentage of GDP, also called quasi-monetary availability. This would be a measure of liquidity. This indicator is used to gauge the ability of banks to honor their commitments on the due dates and fulfill their basic function of financing the economy.

C.Financial Structure of banks: it is measured by the ratio of "equity relative to total assets." This ratio reflects the autonomy and financial independence of banks. It determines the distribution of its financial resources between liabilities and equity.

D.Market capitalization as percentage of GDP: it reflects the weight of the stock market in financing the economy. The higher the index of securities is important, the more access to liquid assets is easier and less expensive.

- Macroeconomic stability variables

A.Inflation: Price stability is important to the success of the financial development process. In a context of moderate inflation and low volatility, nominal interest rates are not excessively high and permit to award the problem of bankruptcy indebted financial institutions. Banks are no longer forced to engage in a price war to attract the maximum deposits.

B. Current account deficit: a chronic and high current account deficit requires the State to make use of the domestic banking system to finance privileged cost on the detriment of its interest margin. Similarly if the deficit persists, it reduces the confidence of local and foreign investors. Therefore any form of above bonds becomes impossible and governments will be reluctant to lift their hold on financial resources.

Institutional variables

A. Index of credit information: The scope of the availability and reliability of the information provided by private and public organizations facilitates the credit decision's bank. An increase in this range reduces the information asymmetry between informed investors and uninformed ones. In this context, uninformed investors abandon the search for private information which becomes more expensive. According to the World Bank, the index of credit information varies from 0 to 8 . The higher the value, the higher the credit information is available.

B. The index of the quality of the law: According to Montiel (1995), the State must provide effective legal structure and a well-established property rights. This is very important if we consider the requests for guarantees on the part of banks. Indeed, on one hand, potential borrowers are often deprived of banking system because they have no duly established titles. On other hand, banks have doubt on fair justice when they take risk of lending to suspect agent. The index of the strength of legal rights measures how the bankruptcy laws and safeguards to protect the rights of borrowers and lenders and facilitate loans. The index ranges from 0 to 12 and the higher the rating, the higher the laws in place are established to allow better access to credit.

- Initial level of economic and human development variables, also known as control variables

A. private investment rate as a percentage of GDP is measured by gross fixed capital formation over the change in private savings

B. Trade openness of the economy: It is measured by the volume of exports plus imports to GDP

C. Human capital: It is measured by the enrollment rate in higher. 
In summary, the following table shows the extent and the expected impact of all variables in the model.

Table 1. Definition and Measurement of Variables

\begin{tabular}{lll}
\hline Variables & Measurement & Expected sign \\
\hline Dependent variable & & \\
\hline $\begin{array}{l}\text { Domestic credit to private sector (\% of } \\
\text { GDP), noted DCPS }\end{array}$ & $\begin{array}{l}\text { Domestic credit to private sector refers to financial resources } \\
\text { provided to the private sector by financial corporations, such as } \\
\text { through loans, purchases of non-equity securities, and trade } \\
\text { credits and other accounts receivable, that establish a claim for } \\
\text { repayment. }\end{array}$ \\
\hline
\end{tabular}

\begin{tabular}{llll}
\hline Independent variables & & \\
\hline Financial and banking variables & & \\
\hline $\begin{array}{l}\text { nonperforming loans Bank to total } \\
\text { gross loans }(\%), \text { noted NPL }\end{array}$ & $\begin{array}{l}\text { Is measured by the value of nonperforming loans divided by } \\
\text { the total value of the loan portfolio (including nonperforming } \\
\text { loans before the deduction of specific loan-loss provisions). }\end{array}$ & Négative \\
\end{tabular}

\begin{tabular}{lll}
\hline $\begin{array}{l}\text { Money and quasi money as \% of GDP, } \\
\text { noted M2 }\end{array}$ & $\begin{array}{l}\text { Is the sum of currency outside banks, demand deposits other } \\
\text { than those of the central government, and the time, savings, and } \\
\text { foreign currency deposits of resident sectors other than the } \\
\text { central government. }\end{array}$
\end{tabular}

Financial structure of banks, noted Is the Equity to total assets ratio. Equity is the capital and EQTA reserves which include funds contributed by owners, retained earnings, general and special reserves, provisions, and valuation adjustments. Total assets include all non financial and financial assets.

\begin{tabular}{llll}
\hline $\begin{array}{l}\text { Market capitalization of listed } \\
\text { companies (\% of GDP), noted } \\
\text { Market_value }\end{array}$ & $\begin{array}{l}\text { Market capitalization (also known as market value) is the share } \\
\text { price times the number of shares outstanding. }\end{array}$ & Positive \\
\hline Macroeconomic stability variables & & & \\
\hline $\begin{array}{l}\text { Current account balance (\% of GDP), } \\
\text { noted CAB }\end{array}$ & $\begin{array}{l}\text { Current account balance is the sum of net exports of goods and } \\
\text { services, net primary income, and net secondary income. }\end{array}$ & $\begin{array}{l}\text { measured by the consumer price index reflects the annual } \\
\text { percentage change in the cost to the average consumer of } \\
\text { acquiring a basket of goods and services that may be fixed or } \\
\text { changed at specified intervals, such as yearly. }\end{array}$ & Negative \\
\hline Inflation, noted inflation & &
\end{tabular}

Institutional variables

Strength of legal rights index $(0=$ weak Strength of legal rights index measures the degree to which to $12=$ strong), noted Law collateral and bankruptcy laws protect the rights of borrowers and lenders and thus facilitate lending. The index ranges from 0 to 12 , with higher scores indicating that these laws are better designed to expand access to credit.

Credit information index $(0=$ low to Depth of credit information index measures rules affecting the $8=$ high), noted info_crédit $\quad$ scope, accessibility, and quality of credit information available through public or private credit registries. The index ranges from 0 to 8 , with higher values indicating the availability of more credit information, from either a public registry or a private office, to facilitate lending decisions.

es (control variables)

\begin{tabular}{llll}
\hline \multicolumn{3}{l}{ Economic and human development variables (control variables) } \\
\hline Human capital, noted Hum_Cap & $\begin{array}{l}\text { measured by the level of the population with higher level of } \\
\text { education; }\end{array}$ & Positive \\
\hline $\begin{array}{l}\text { Investment } \\
\text { investment } \% \text { of } \text { GDP), noted }\end{array}$ & $\begin{array}{l}\text { Measured by Gross fixed capital formation plus the variation of } \\
\text { private saving (formerly gross domestic fixed investment) }\end{array}$ & Positive \\
$\begin{array}{l}\text { Commercial opening of economy (\% of } \\
\text { GDP), noted trade }\end{array}$ & $\begin{array}{l}\text { Measured by the sum of exports and imports of goods and } \\
\text { services measured as a share of gross domestic product. }\end{array}$ & Uncertain \\
\hline
\end{tabular}

All variables are taken from the Global Development Network Growth Database (GDNGD), the World Development Indicators (WDI) and OECD countries database.

\subsection{Sample Selection}

Our panel is formed of 38 countries, split into two groups of samples. The first group (G1) consists of 23 developing countries. Although, these countries, have begun, since the $80 \mathrm{~s}$, economic and financial reforms to liberalize their financial services they haven't the expected benefits. On the contrary some of them (Argentina, Mexico, Thailand, 
Malaysia) have been shaken by financial and banking crises very expensive in real terms. Other countries (Bolivia, Chile, Ecuador, Egypt, Indonesia, Peru, Philippines and Tunisia) are stuck in a vicious circle situation and could not take advantage of the reforms. (Note 1)

The second group (G2) includes 15 developed countries extracted from OECD countries. These countries have begun reforms since the 70's to restructure and modernize their financial systems. Subsequently, they adopted a financial liberalization policy and consequently initiated progress in improving their social and economic well-being. (Note 2)

The purpose of choosing these two groups of samples is to identify the determinants of financial development in each group of countries.

\subsection{Estimate Model}

The model takes the following general form: $Y_{i t}=\alpha_{i}+\beta_{i} B F V_{i t}+\delta_{i} E S V_{i t}+\lambda_{i} L I V_{i t}+\gamma_{i} E H V_{i j t}+\varepsilon_{i t}$ where :

$\mathrm{FBV}_{\mathrm{it}}$ : banking and financial variables

$\mathrm{ESV}_{\mathrm{it}}$ : economic stability variables

LIV $_{\text {it: }}$ Legal and institutional variables

$\mathrm{EHV}_{\mathrm{it}}$ : economic and human variables

$\varepsilon_{\mathrm{it}}$ : the error term with $\mathrm{E}\left(\varepsilon_{\mathrm{it} 1)}=0\right.$ and $\mathrm{E}\left(\varepsilon_{\mathrm{it}}{ }^{2}\right)=\sigma_{\varepsilon}^{2}$

This equation could be interpreted as part of a panel analysis in the following expanded form:

$$
Y_{i t}=\alpha_{i}+\sum_{j=1}^{j=K} \beta_{i j} F B V_{i j t}+\sum_{j=1}^{j=M} \delta_{i j} E S V_{i j t}+\sum_{j=1}^{j=M} \lambda_{i j} L I V_{i j t}+\sum_{j=1}^{j=M} \gamma_{i j} E H V_{i j t}+\varepsilon_{i t}
$$

\subsubsection{Test specification}

The test specification or test for the existence of individual effects, is whether we are entitled to assume that the theoretical model is the same for all countries $\left(\alpha_{i}=\alpha ; \beta_{i}=\beta ; \delta_{i}=\delta ; \lambda_{i}=\lambda\right.$ et $\left.\gamma_{i}=\gamma\right)$ or the specificities of each country must be considered.

Four regressions for each group of countries will be established. The 1st regression considers only the financial and banking variables. In the $2 \mathrm{nd}, 3 \mathrm{rd}$ and 4 th regression we gradually introduced variables respectively human and economic development, macroeconomic stability variables and variables of the legal and institutional environment, so we have:

$$
\begin{aligned}
y_{i t 1}= & \alpha_{i}+\beta_{i} F B V_{i, t}+\varepsilon_{i, t} \quad(1 \mathrm{st} \text { regression }) \\
y_{i t 2}= & \alpha_{i}+\beta_{i} F B V_{i, t}+\gamma_{i} E H V_{i, t}+\varepsilon_{i, t} \quad(2 \text { nd regression) } \\
y_{i t 3}= & \alpha_{i}+\beta_{i} F B V_{i, t}+\delta_{i} E S V_{i, t}+\varepsilon_{i, t} \quad(3 r d \text { regression }) \\
y_{i t 4}= & \alpha_{i}+\beta_{i} F B V_{i, t}+\lambda_{i} L I V+\varepsilon_{i, t}(4 \text { th regression) } \\
& \forall i \in[1,23], \forall t \in[1997,2013] \text { for the first group }(G 1) \\
& \forall i \in[1,15], \forall t \in[1997,2013] \text { for the } \sec \text { ond group }(G 2)
\end{aligned}
$$

The results of the test specification or existence of individual effects in the first and second group are summarized in Table 2.

Table 2.Test Specification or Test for the Existence of Individual Effects

\begin{tabular}{cllllll}
\hline \multicolumn{7}{c}{ F test that all $\mathrm{u}_{-} \mathrm{i}=0$} \\
\hline Regression $\mathrm{n}^{\circ}$ & G1 (developing countries) & & G2 (developed countries) \\
\hline 1 & $\mathrm{~F}(22,364)=$ & 64.63 & Prob $>\mathrm{F}=0.0000$ & $\mathrm{~F}(14,236)=$ & 27.68 & Prob $>\mathrm{F}=0.0000$ \\
\hline 2 & $\mathrm{~F}(22,361)=$ & 79.35 & Prob $>\mathrm{F}=0.0000$ & $\mathrm{~F}(14,233)=$ & 60.69 & Prob $>\mathrm{F}=0.0000$ \\
\hline 3 & $\mathrm{~F}(22,362)=$ & 66.16 & $\mathrm{Prob}>\mathrm{F}=0.0000$ & $\mathrm{~F}(14,234)=$ & 31.60 & Prob $>\mathrm{F}=0.0000$ \\
\hline 4 & $\mathrm{~F}(22,362)=$ & 53.07 & Prob> F $=0.0000$ & $\mathrm{~F}(14,234)=$ & 24.27 & Prob $>\mathrm{F}=0.0000$
\end{tabular}

At degree of risk of 5\%, we reject the null hypothesis of equality of constants for the two groups (p-value $<5 \%$ ). It is therefore necessary to introduce the individual effects.

3.3.2 Hausman specification test

This test can be interpreted as a test specification: Under $\mathrm{H} 0$, the model can be specified with random individual effects and must retain estimator MCG. Under the alternative hypothesis Ha, the model must be specified with fixed individual effects and must retain the within estimator. 
The results of the statistics of Hausman test for both groups are summarized in Table 3 .

Table 3. Hausman Tests

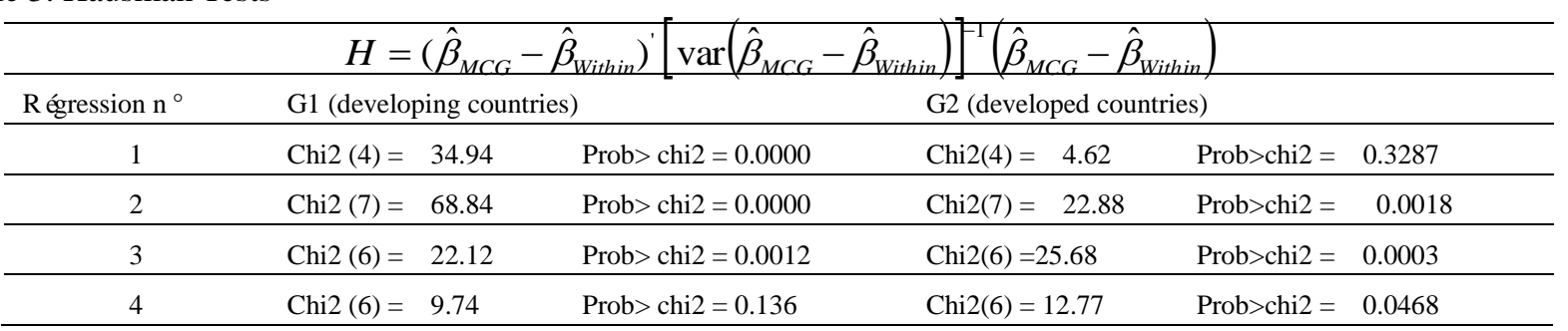

For the first group (G1), we reject the null hypothesis of no correlation between the individual effects and the explanatory variables for the first three regressions (P-value $<5 \%)$ and retains the fixed effects model. As for the fourth regression, we accept the null hypothesis (P-value $>5 \%$ ), and retains the random effects model.

For the second group (G2), we accept the null hypothesis of no correlation (P-value $>5 \%$ ), and retains the random effects model for the first regression. As for the $2 \mathrm{nd}$, the $3 \mathrm{rd}$ and 4 th regression, we reject the null hypothesis (P-value $<5 \%$ ) and retains the fixed effects model.

\section{Results and Discussion}

The estimation results for two samples are listed in Tables 4 and 5.

\subsection{Variables related to the financial and banking sector}

Non-performing loans, the market capitalization as a percentage of GDP and almost monetary availability as a percentage of GDP are significant and have the expected sign for both groups of countries.

The financial structure (EQTA) is positive but not significant. We conclude that financial development is insensitive to the financial structure of banks and to their autonomy and financial independence.

The rate of non-performing loans (NPL) is negative and significant. This result is the outcome of Kaminsky and Reinhart (1999), Kabra and Dash (2010) and Espinoza and Prasad (2010). The negative sign implies that the NPL mismanagement of assets classified systematically increases credit risk and a loss on the interest margin of banks and financial institutions. The NPL affect bank profitability and consequently hinder the granting of loans and financial development.

M2 ratio in percentage of GDP is positive and significant. It means that the money supply and quasi-monetary promote financial development. Nevertheless, a lack of liquidity reflects the inability of banks and financial institutions to meet their cash obligations when due and to honor their commitments to creditors and to the financing of the economy in general.

Market capitalization in GDP percentage has a positive and significant effect on financial development. This was verified by Aceh and Jovanovic (1993) and Levine and Zervos (1996). Indeed, the more the stock market is liquid and efficient, the more sources of financing of the economy are more available and less expensive. Subscription on stock exchange and or the opening of the capital account of already listed companies improve financing conditions in the stock market and promote financial development.

\subsection{Variables related to economic and human development}

The investment and human capital are positive and significant for both samples. While, trade openness is positive and significant for the sample of developed countries and negative and significant for the developing countries. This finding means in part that the level of economic and human development is an absolute imperative for financial development. As against the trade openness effect varies according to the economic and financial conditions in the countries.

- The variable "investment as a percentage of GDP" is positive and significant. This implies that the efficiency of financial development is conditioned in part of the initial level of economic development, combined with public and private investment rates.

- The variable "enrollment rate in higher education" representing among others the development of human capital, is positive and significant. Thus higher education investment is a source of knowledge accumulation and innovation, and consequently leads to improved financial development. This result is the outcome of Schultz (1961), Frankel (1962) and Becker (1975)

- The variable "Trade openness as a percentage of GDP" is positive and significant for developed countries and negative and significant for developing countries. We conclude that the negative sign of this variable in developing countries could be explained by a lack of preventive measures and precautions for the protection and consolidation of their 
financial system before the commercial opening of their economies. Several authors point out that the link is uncertain and is not systematic (Grossman and Helpman (1990), Fontagné and Guérin (1997) Busson and Villa (1997))

\subsection{Variables related to macroeconomic stability}

the results found in the first group are contrary to those of the second group:

For group 1, the results found lead to a significant negative relationship between inflation and financial development on one hand and negative and not significant between the current account deficit and financial development on the other hand.

For group 2, the results found show that the relationship between inflation and financial development is negative and significant. While that between the current account deficit and financial development is negative but insignificant.

- Inflation is negative and insignificant in developed countries. This result corroborates that of Hanson and Rocha (1986) and Irland (1984). We conclude that in these countries, monetary instability does not necessarily hinder financial development. Instead, inflation appears to be the result of a hard competition at interbank excessive granting consumer loans. While in developing countries, inflation affects financial development through a bad monetary policy that systematically hinders the granting of credits.

- The current account deficit is negative and significant. This result implies that in developed countries the current account deficit exists, it significantly affects financial development. While in developing countries, the relationship between the current account deficit and financial development is absent.

Table 4. Estimates Results

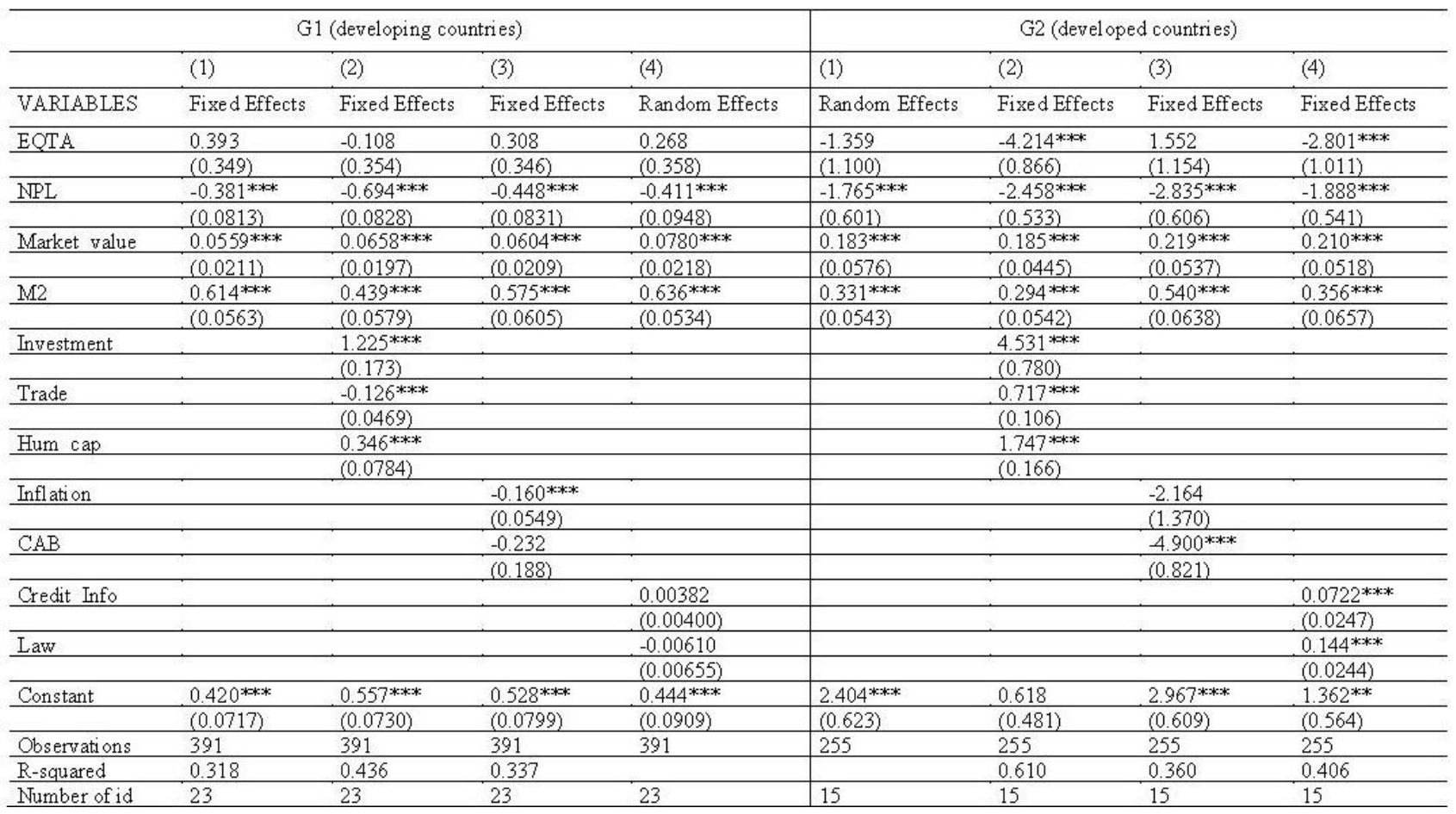

Standard errors in parentheses $* * * \mathrm{p}<0.01, * * \mathrm{p}<0.05, * \mathrm{p}<0.1$

\subsection{Variables related to the legal and institutional environment}

The results found show that these variables have a positive effect on financial development only in developed countries:

- The positive and significant sign of the variable (Law) shows that in developed countries (G2), as adherence to market forces and contract enforcement are important, as the financial development effect is pronounced (De-Silianes and Vishny (1997) and Chinn and Ito (2002))

- The index of credit information is positive and significant that in developed countries (G2). This implies that the higher the index, the greater the access to information is available. The extent of the relevance and reliability of information from public and private organizations reduce the risk of insolvency and increases the performance and financial development. 


\section{Conclusion}

From a more general point of view, financial development has three goals. The first is to allow restructuring and modernization of banks by privatization and transformation of information and communication technologies as well. The second is to ensure optimal allocation of resources and better diversification of risks. The third is to make positive real interest rates in order to lead a successful financial liberalization. However, achieving these objectives is subject to certain conditions and measures such as the initial condition of financial and banking system, the existence of a minimum level of economic development, the lack of an excessive public deficit, the preservation of macroeconomic stability and the existence of an adequate legal and institutional framework.

In reviewing the empirical results, we deduce that only the determinants related to the banking and financial sector and the initial level of economic and human development are standard and unanimous in all countries. The determinants related to the macroeconomic stability and the legal and institutional environment is variable and change their signs and significances according to the specific case of each country.

The results obtained from multiple panel data regression corroborate our initial hypothesis and show that financial development depends on the weight of non-performing loans, the liquidity rate of the economy, the market capitalization, the rate of investment economics, the trade openness rate and the importance given to human capital. Conversely, the determinants related to macroeconomic stability and the development of the legal and institutional framework are neither general nor generalizable. They seem significant in developed countries.

The disparity of financial development between the two groups lies mainly in the quality of the legal and institutional framework and the run of the current deficit of the developed countries.

However, the satisfaction of all these determinants is not in itself a guarantee of absolute success. It should nevertheless develop a rhythm and an optimal order for all stages of financial development process.

\section{References}

Arteta, C., Eichengreen, B., Wyplosz, C. (2001, March). When does Capital Account Liberalization Help More Than it Hurts? Paper Presented at the conference celebrating Assaf Razin's 60th Birthday, March 25-26, Tel Aviv University.

Atje, R., \& Jovanovic, B. (1993). Stock Markets and Development. European Economic Review, 37, 632-640.

Beck, T., Lunderberg, M., \&Majnoni, G. (2001). Financial Intermediary Development and Growth Volatility; do Intermediaries Dampen or Magnify Shocks? World Bank Policy Research.Working Paper.

Becker, G. (1975). Investment in Human Capital: Rates of Return. NBER Chapters, in Human Capital: A Theoretical and Empirical Analysis, with Special Reference to Education, 2nd ed., 45-144.

Ben-Saada, M., \& Khalfaoui, H. (2011). Les conditions du développement des systèmes financiers et leurs effets sur la croissance économique : une approche en données de panel. La Revue des Sciences de Gestion 2011/3 n²49-250. http://dx.doi/10.3917/rsg.249.0021

Busson, F., \& Villa, P. (1997). Croissance et spécialisation. Revue Economique, vol. 48, n6, novembre. http://dx. http://dx.doi/10.2307/3502526

Chinn, M. D., \& Ito, H. (2002). Capital Account liberalization, institutions and financial development: Cross Country Evidences. NBER Working Paper Series,8967, June.

Dash, M., \& Kabra, G. (2010). The Determinants of Non-Performing Loans Assets in Indian Commercial Bank: A Econometric Study. Middle Eastern Finance and Economics, 7, 94-106.

De Gregorio, J., \& Guidotti, P. E. (1995). Financial development and economic growth. World Development, 23-3, pp. 433-448.http://dx. doi/10.1016/0305-750x

Edwards, S. (2001), Capital Mobility and Economic Performance: Are Emerging Economies Different? NBER Working Paper, 8076, January.

Espinoza, R., \& Prasad, A. (2010), Non-Performing Loans in the GCC banking systems and their macroeconomics effects. IMF working paper.

Fontagné, L., \& Guérin, J. L. (1997). L'ouverture, catalyseur de la croissance. Economie Internationale, 71, 135-167

Frankel, M. (1962). The Production Function in Allocation and Growth: a Synthesis. American Economic Review, 52(5).

Fry, M. J. (1997). In favour of Financial Liberalization. The Economic Journal, May 1997, 107(442), 754-770.

Greenwood, J., \& Jovanovic, B. (1990).Financial Development, Growth and the Distribution of Income. Journal of 
Political Economy, 18(5), 1076-1107. http://dx.doi.org/10.1086/261720

Grossman, G., \& Helpman, E. (1990).Comparative Advantage and Long-run Growth. American Economic Review, 80(4), 796-815.

Grossman, G.M., \& Yanagawa, N. (1993). Asset bubbles and endogenous growth. Journal of Monetary Economics, Elsevier, 31(1), 3-19.

Hanson, J., \& Rocha, R. (1986). High Interest Rate, Spread and the Cost of Intermediation: Two Studies. World Bank Industry and Finance Series, 18.

Johnston, R. B., \& Pazarbasioglu, C. (1995). Linkages Between Financial Variables, Financial Sector Reform and Economic Growth and Efficiency. IMF Working Paper .

Kaminsky, G., \& Reinhart, C. (1999). The Twin Crises: The Causes of Banking and Balance of Payments Problems. American Economic Review, 89, 473-500. http:dx.doi/10.1257/aer.89.3.473

Klein, M., \& Olivei, G. (2000). Capital Account Liberalization, Financial Depth, and Economic Growth. (unpublished; Somerville, Mass: Tufts University).

Laporta, R., De-Silianes, F. L., Shleifer, A., Vishny, R. W. (1996). Law and Finance, NBER, working paper, 5661

Laporta, R., De-silianes, F. L., Shleifer, A., \& Vishny, R. W. (1997). Trust in large organizations. American EconomicReview, 87, 333-338

Levine, R., \& Zervos, S. (1996). Stock Market, Banks, and Economic Growth, View and Agenda. American Economic Review, 88(3), 537-558. http://dx.doi.org/10.1016/S0304-3932(00)00017-9

McKinnon, R. I. (1991). The Order of Economic Liberalisation: Financial Control in the Transition to A Market Economy. The Johns Hopkins University Press, Baltimore and London, 1st Edition.

Montiel, P. J. (1996). Financial Policies and Economic Growth: Theory, Evidence and Country-Specific Experience from Sub-Saharan Africa. Journal of African Economies, 5(3), 65-98.

Rajan, R. G., \& Zingales, L. (2003). The great reversals: the politics of financial development in the twentieth century. Journal of Financial Economics, Elsevier, 69(1), 5-50.

Schultz, T. (1961). Investment in Human Capital. American Economic Review, 51, 1-17.

Schumpeter, J. (1912). Banks, Credit and the Financial System. Historian of Economic. Edited by Moss L, Rutledge, $167-177$

\section{Notes}

Note 2. Developing countries are: Algeria, Argentina, Bolivia, Brazil, Chile, China, Ecuador, Egypt, Arab Rep., India, Indonesia, Israel, Jordan, Malaysia, Mexico, Morocco, Peru, Philippines, Russian Federation, South Africa, Thailand, Tunisia, Turkey and Uruguay

Note 3. Developed countries are: Australia, Denmark, Finland, France, Germany, Greece, Iceland, Ireland, Italy, Japan, Luxembourg, Portugal, Sweden, Switzerland and United States

\section{(cc) EY}

This work is licensed under a Creative Commons Attribution 3.0 License. 